\title{
Prevalence of Polycystic Ovary Syndrome (PCOS) Among Infertile Women Attending Fertility Clinic at a University Teaching Hospital in Nigeria
}

\author{
Vaduneme Kingsley Oriji (FWACS) ${ }^{1,2 *}$ and Chidi Onwuegbulam (FWACS) ${ }^{2}$ \\ ${ }^{1}$ Department of Obstetrics and Gynaecology, University of Port Harcourt, Nigeria \\ ${ }^{2}$ University of Port Harcourt Teaching Hospital, Nigeria
}

Submission: July 01, 2019 ; Published: July 10, 2019

*Corresponding author: Vaduneme Kingsley Oriji, Department of Obstetrics and Gynaecology, University of Port Harcourt, Nigeria

\begin{abstract}
Background: Polycystic ovary syndrome (PCOS) is a major cause of annovulatory infertility worldwide. It is important to determine the prevalence and characteristic features of PCOS in different environment including the sub-Saharan Africa.

Objective: The objective is to determine the prevalence and the prevalent phenotypic characteristics of infertile patients with PCOS attending the fertility clinic of the University of Port Harcourt Teaching Hospital.

Methodology: This was a cross-sectional study of 174 women attending the fertility clinic of the University of Port Harcourt Teaching Hospital between January 2016 and June 2016. Data collected from each patient were age, parity, height, weight, degree of hirsutism (using modified Ferriman-Gallway scoring), antral follicle count and ovarian volume. Others are serum follicle stimulating hormone (FSH), luteinizing hormone (LH), prolactin, progesterone and testosterone determined for each patient. Data analysis was done with SPSS statistical package version 17.0 The means and proportions of characteristics of infertile women with PCOS were compared to that of infertile women without PCOS using the student t-test and chi square test respectively. The level for statistical significance was set at $\alpha<0.05$ at $95 \%$ confidence interval.

Results: Polycystic ovarian syndrome (using Rotterdam criteria) occurred in 16.7\% (29) of infertile patients. Hirsutism occurred in 55.2\% (16) of infertile women with PCOS but in $12.6 \%$ (16) of infertile women with normal ovaries $(\mathrm{P}<0.001)$. Oligomenorrhoea occurred in $27.5 \%$ (8) of infertile women with PCOS and in $2.4 \%$ (3) of infertile women with normal ovaries ( $\mathrm{P}=0.01)$. Significantly more infertile women PCOS had anovulation as the mean mid-luteal progesterone $(7.54 \pm 6.3 \mathrm{ng} / \mathrm{ml})$ was less than that for women with normal ovaries $(17.89 \pm 10.8 \mathrm{ng} / \mathrm{ml})$ $\mathrm{P}=0.015$ and higher mean testosterone level was also observed in infertile women with PCOS $(0.94 \pm 0.08 \mathrm{IU} / \mathrm{L})$ than in those with normal ovaries $(0.47 \pm 0.31 \mathrm{IU} / \mathrm{L}) \mathrm{P}<0.001$.
\end{abstract}

Conclusion: The prevalence of PCOS in women with infertility was $16.7 \%$. The infertile patients with PCOS had statistically higher occurrence of annovulatory cycle with oligomenorrhoea, hirsutism and serum testosterone levels compared to infertile women with normal ovaries.

Keywords: Infertility; Polycystic Ovary Syndrome; Hyperandrogenaemia; Hirsutism; Oligomenorrea; Anovulatory infertility

Abbreviatations: PCOS: Polycystic Ovary Syndrome; FSH: Follicle Stimulating Hormone; LH: Luteinizing Hormone; PCO: Polycystic Ovaries; SHBG: Sex Hormone Binding Globulin

\section{Introduction}

The vast majority of annovulatory infertility is caused by PCOS. PCOS has been severally documented as the commonest endocrine cause of anovulation and infertility [1-4]. Reports of classical appearance of polycystic ovaries (PCO) in normal healthy women without any endocrinopathy have been made, and so it is important to recognize a clear distinction between the normal women whose ovaries appear polycystic from

women with clinical features that warrant the diagnosis of PCOS. Balen et al defined polycystic ovary as an ovary with at least 12 or more follicles measuring $2-9 \mathrm{~mm}$ each in diameter in a single plain or an increased ovarian volume of more than $10 \mathrm{~cm} 3$ using transvaginal ultrasound scan [5]. The cysts in polycystic ovaries refers to antral follicles with arrested development. PCOS has been estimated to cause up to $75 \%$ of annovulatory infertility in some group of women [6]. It is also estimated that 
nearly one out of every 4 women have polycystic ovaries (PCO) with a quarter of these women developing symptoms of PCOS $[2,7]$. The prevalence of PCOS varies widely across the globe and the population under study. This depends on ethnicity, race environment and the criteria used to make diagnosis of PCOS [6,8]. Globally, the prevalence of 5-10\% and 17-22\% [919] has been reported for PCOS and PCO respectively using the Rotterdam criteria. In sub Saharan Africa, studies on prevalence of PCOS are scanty and values between $16 \%$ to $32 \%$ have been quoted from different centres [20].

The diagnosis of PCOS, using Rotterdam criteria, is made when at least two of the three identifying features are present. The presence of clinical or laboratory evidence hyperandrogenism, oligo/anovulation and polycystic ovaries on transvaginal scan are seen in a woman [21]. Two other criteria have been used for the diagnosis of PCOS, the USA National Institute of Health and the Androgen excess society, possibly accounting for the different prevalence estimates of PCOS in the past. It is now generally accepted that the broad Rotterdam criteria (2011) for the diagnosis of PCOS be maintained and specific patient phenotypes identified for each patients with PCOS as this has implications for early and late complications of PCOS [22]. PCOS is a clinical syndrome with varying clinical and biochemical features. It presents as a spectrum of endocrine, reproductive and metabolic disorders which could be mild affectations in some patients but severe disturbances in others. The key features of hyperandrogenism and anovulatory cycle, recognized as the classic phenotype in PCOS, occur in varying proportions in different patients $[10,15,17,1,20-22]$. Hyperandrogenism may present with hirsutism, acne or alopecia and is recognized biochemically as elevated male steroid hormones such as testosterone and androstenedione or DHEAS. It is also presented as free androgen index from the depressed serum levels of sex hormone binding globulin (SHBG) in women with PCOS. Therefore, some women with PCOS may show marked androgenic effects. The disturbance in reproduction presents as oligo-menorrhea, amenorrhea, or dysfunctional uterine bleeding which is associated with anovulation and results in infertility [17-19]. Serum levels of hormones in the Hypothalamo-PituitaryOvarian axis may become deranged in women with PCOS. This is responsible for some of other endocrine manifestation of PCOS such as elevation of serum LH resulting in an increased LH/FSH ratio in some patients $[8,23]$. It has also been identified that PCOS can affect response to ovulation induction agents and can also result in early pregnancy miscarriages in infertile women [24-26]. However, the appearance of polycystic ovaries alone has not been shown to have any significant impact on the fertility of women who conceive naturally when they have no features suggestive of PCOS [23].

\section{Aims and Objectives}

The aim of the study is to determine the prevalence, clinical and laboratory characteristics of polycystic ovary syndrome in infertile women attending the fertility clinic at the University of Port Harcourt Teaching Hospital.

\section{Methodology}

This is a prospective cross sectional study involving infertile women attending the fertility clinic of University of Port Harcourt Teaching Hospital from June to December 2016. This hospital is a tertiary health institution located about 15 kilometers from Port Harcourt city. The sample size of 174 was determined using the formula for determining sample size for descriptive studies 46 with the average prevalence rate of PCOS at $13 \%$ and 1.95 as the proportion of normal distribution corresponding to the required of significance level of $5 \%$.

All consenting infertile women attending the clinic were recruited for the study. The socio-demographic information, clinical and laboratory characteristics of each patient was collected with a questionnaire. The data collected include age, marital status, occupation, level of educational, parity, menstrual history (with regular menses as menstrual cycles recurring every 21-35days), oligomenorrhoea defined as menstrual cycles longer than 35 days or less than 10 menstrual cycles per year. Physical examination was done for each patient and the data generated are height $(\mathrm{m})$, weight $(\mathrm{kg})$, score for hirsutism using modified Ferriman-Gallway score and presence of acne vulgaris. A transvaginal ultrasound scan (Mind-ray Z5 model ultrasound equipment) was conducted on each patient to determine the number of antral follicles and the volume of each ovary. Venous blood was collected and serum levels of FSH, LH, Prolactin and testosterone were all determined in the in the follicular phase of the menstrual cycle. Venous blood was also collected in the mid luteal phase for the determination of serum progesterone. All serum hormone analyses were conducted using enzyme linked immunosorbent assay (Stat Fax 2600 ELISA System, USA)

\section{Result}

The mean age of infertile women studied was $33.18 \pm 4.87$ years with a range of 15-45 years. Majority of the women were within the age range of 25-34 years and the age range was 15-45years. The mean age of infertile women with polycystic ovaries (PCO) and those with normal ovaries were $33.43 \pm 5.0$ and $32.49 \pm 4$.4years. In the 174 infertile patients studied, about $73 \%$ (127) had normal ovaries while polycystic ovaries and polycystic ovarian syndrome were identified in $10.3 \%$ (18) and $16.7 \%$ (29) of the infertile women respectively. Oligomenorrhoea was statistically more in those with PCOS $17 \%$ (8) compared to $2.4 \%$ (3) of the infertile women with normal ovaries $(\mathrm{P}=0.01)$ see Table 1. 


\section{Journal of Gynecology and Women's Health}

Table 1: Social and physical attributes of the studied population.

\begin{tabular}{|c|c|c|c|c|}
\hline Variables & $\begin{array}{l}\text { Women with Normal Ovaries } \\
\text { ( } \mathrm{N}=127)\end{array}$ & $\begin{array}{l}\text { Women with Polycystic } \\
\text { Ovaries Alone }(\mathrm{N}=18)\end{array}$ & $\begin{array}{c}\text { Women with Polycystic Ovary } \\
\text { Syndrome }(\mathrm{N}=29)\end{array}$ & P Value \\
\hline \multicolumn{5}{|c|}{ Age } \\
\hline$<35$ years & $80(97.6 \%)$ & $15(88.2 \%)$ & $25(83.3 \%)$ & \\
\hline$\geq 35$ years & $47(2.4 \%)$ & $2(11.8 \%)$ & $5(16.3 \%)$ & \\
\hline \multicolumn{5}{|c|}{ Parity } \\
\hline 0 & $102(80.3 \%)$ & $14(82.3 \%)$ & $23(80.0 \%)$ & \\
\hline 1 & $18(14.2 \%)$ & $3(17.6 \%)$ & $5(16.6 \%)$ & \\
\hline$>1$ & $7(5.5 \%)$ & $1(0.00 \%)$ & $1(3.4 \%)$ & \\
\hline \multicolumn{5}{|c|}{ Duration of Menstrual Flow (Days) } \\
\hline$<2$ days & $5(3.9 \%)$ & $0(0.0 \%)$ & $1(3.4 \%)$ & \\
\hline 2 - 7days & $120(94.5 \%)$ & $17(100 \%)$ & $21(72.4 \%)$ & 0.68 \\
\hline$>7$ days & $2(0.15)$ & $0(0.0 \%)$ & $7(24.1 \%)$ & \\
\hline \multicolumn{5}{|c|}{ Menstrual Cycle Length (Days) } \\
\hline$<21$ & $0(0 \%)$ & $0(0 \%)$ & $2(6.9 \%)$ & \\
\hline $21-35$ & $124(97.6)$ & $16(89.9 \%)$ & $19(65.5 \%)$ & \\
\hline$>35$ & $3(2.4 \%)$ & $2(11.1 \%)$ & $8(27.5 \%)$ & 0.01 \\
\hline \multicolumn{5}{|c|}{ Body Mass Index (Bmi) } \\
\hline 18.5-24.9 (normal) & $35(27.6 \%)$ & $2(11.8 \%)$ & $3(10.0 \%)$ & \\
\hline 25-29.9(pre-obesity) & $55(43.3 \%)$ & $11(58.8 \%)$ & $22(73.3 \%)$ & \\
\hline 30.0-34.9(class1) & $33(26.0 \%)$ & $4(23.5 \%)$ & $3(10.0 \%)$ & 0.40 \\
\hline $35.0-39.9$ (class2) & $4(3.1 \%)$ & $1(5.9 \%)$ & $1(2.8 \%)$ & \\
\hline$>40$ (class 3$)$ & $0(0.0 \%)$ & $0(0.0 \%)$ & $1(2.8 \%)$ & \\
\hline \multicolumn{5}{|c|}{ Hirsutism (F-G) Score Score } \\
\hline $0-8$ & $111(87.4 \%)$ & $16(94.2 \%)$ & $13(44.8 \%)$ & \\
\hline $8-15$ & $16(12.6 \%)$ & $1(5.8 \%)$ & $16(55.2 \%)$ & $<0.001$ \\
\hline$>15$ & 0 & 0 & 0 & \\
\hline \multicolumn{5}{|c|}{ Acne } \\
\hline Present & $40(31.5 \%)$ & $14(77.8 \%)$ & $12(41.3 \%)$ & 0.03 \\
\hline Absent & $87(68.5 \%)$ & $4(22.2 \%)$ & $17(58.6 \%)$ & \\
\hline
\end{tabular}

A total of 39 out of the 174 infertile patients had elevated testosterone levels. Twenty-four (83\%) out of twenty-nine of those with PCOS had elevated testosterone. Twenty-six (92\%) of infertile women with PCOS had at least one polycystic ovary and $62 \%(18)$ of those with PCOS had anovulation. Obesity occurred

Table 2: Ultra-sonographic features in the studied population.

\begin{tabular}{|c|c|}
\hline Ovarian Features & $<\mathbf{1 2}$ Antral Follicles \& Ovarian Vol. $\mathbf{< 1 0 \mathbf { c m } ^ { \mathbf { 3 } }}$ \\
\hline Right Ovary & 137 \\
\hline Left Ovary & 141 \\
\hline
\end{tabular}

There was significantly higher mean testosterone level in infertile patients with PCOS than those with normal ovaries $(0.94 \pm 0.08 \mathrm{IU} / \mathrm{L}$ versus $0.47 \pm 0.31 \mathrm{IU} / \mathrm{L} ; \mathrm{P}<0.001)$. There was significantly lower mean mid luteal phase progesterone level in infertile women with PCOS and those with normal ovaries $(5.54 \pm 5.3 \mathrm{ng} / \mathrm{ml}$ versus $17.89 \pm 10.8 \mathrm{ng} / \mathrm{ml} ; \mathrm{P}=0.015)$. There was no significant difference in the mean luteinizing hormone level in the infertile patients with PCOS and those with normal ovaries (5.12 $\pm 2.5 \mathrm{IU} / \mathrm{L}$ versus $14.5 \pm 1.7 \mathrm{IU} / \mathrm{L} ; \mathrm{P}=0.3)$. The mean follicle more often in the infertile women with normal ovaries compared to women with PCOS (29.1\% versus $12.8 \%$ ) but hirsutism and acne are significantly associated with the women with PCOS than those with normal ovaries (43.1\% versus $31.5 \%)$ and $(55.2 \%$ versus $12.6 \%$ ) See Table 2.

\begin{tabular}{|c|c|}
\hline$\geq \mathbf{1 2}$ Antral Follicles & Ovarian Vol. $\mathbf{~} \mathbf{1 0} \mathbf{c m}^{\mathbf{3}}$ \\
\hline 37 & 36 \\
\hline 28 & 31 \\
\hline
\end{tabular}

stimulating hormone level was higher in the infertile patients with PCOS than in those with normal ovaries $(9.8 \pm 4.08 \mathrm{IU} / \mathrm{L}$ versus $5.01 \pm 2.41 \mathrm{IU} / \mathrm{L} ; \mathrm{P}=0.13$ ). The mean prolactin level in infertile women with PCO was not statistically different from those with normal ovaries $(3.43 \pm 1.53 \mathrm{IU} / \mathrm{L}$ versus $2.96 \pm 1.17 \mathrm{IU} / \mathrm{L} ; \mathrm{P}=0.713$ ). There was also no significant difference in the mean oestradiol level in the infertile patients with PCOS and those with normal

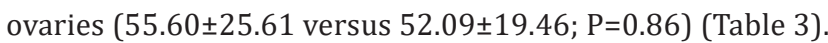


Table 3: Serum Hormone levels of the studied population.

\begin{tabular}{|c|c|c|c|c|}
\hline Variables & $\begin{array}{l}\text { Women with Normal } \\
\text { Ovaries }(\mathrm{N}=127)\end{array}$ & $\begin{array}{l}\text { Women with Polycystic } \\
\text { Ovaries Alone }(\mathrm{N}=18)\end{array}$ & $\begin{array}{l}\text { Women with Polycystic } \\
\text { Ovary Syndrome }(\mathrm{N}=29)\end{array}$ & P Value \\
\hline Mean Testosterone & $0.47 \pm 0.31 \mathrm{IU} / \mathrm{L}$ & $0.4 \pm 0.38 \mathrm{IU} / \mathrm{L}$ & $0.94 \pm 0.08 \mathrm{IU} / \mathrm{L}$ & $<0.001$ \\
\hline Mean LH & $5.12 \pm 2.50 \mathrm{IU} / \mathrm{L}$ & $7.16 \pm 4.40 \mathrm{IU} / \mathrm{L}$ & $14.52 \pm 1.70 \mathrm{IU} / \mathrm{L}$ & 0.3 \\
\hline Mean FSH & $5.01 \pm 2.41 \mathrm{IU} / \mathrm{L}$ & $5.8 \pm 4.08 \mathrm{IU} / \mathrm{L}$ & $9.8 \pm 4.08 \mathrm{IU} / \mathrm{L}$ & 0.13 \\
\hline Mean Prolactin & $29.63 \pm 7.17 \mathrm{IU} / \mathrm{L}$ & $34.03 \pm 6.53 \mathrm{IU} / \mathrm{L}$ & $34.03 \pm 6.53 \mathrm{IU} / \mathrm{L}$ & 0.17 \\
\hline Mean progesterone & $17.89 \pm 10.8 \mathrm{ng} / \mathrm{ml}$ & $9.54 \pm 5.31 \mathrm{ng} / \mathrm{ml}$ & $5.54 \pm 5.35 \mathrm{ng} / \mathrm{ml}$ & 0.02 \\
\hline Mean estradiol & $52.09 \pm 19.46 \mathrm{IU} / \mathrm{L}$ & $50.60 \pm 22.6 \mathrm{IU} / \mathrm{L}$ & $55.60 \pm 25.6 \mathrm{IU} / \mathrm{L}$ & 0.23 \\
\hline
\end{tabular}

\section{Discussion}

This study showed that the prevalence of PCO and PCOS among infertile women at the University of Port Harcourt Teaching Hospital were $10.3 \%$ and $16.7 \%$ respectively. This is comparable to the prevalence of PCOS of $18.1 \%$ in infertile women in Enugu Southern Nigeria, but lower than that found in some centres around the world such as Tanzania (32\%), in Iraq (74.6\%), Iran (69.7\%) and Denmark (68\%) [24,2732]. Most of these reports reflecting the PCOS prevalence in general population and not just in women with infertility. This variation with several other studies may be due to racial or ethnic differences. It may also be due to the average age of the population studied, as wide variations exist in population prevalence studies even when studies were based on the same Rotterdam criteria for the diagnosis of PCOS. Studies have also shown that typical polycystic ovarian morphology appeared to diminish with increasing age, so also the improvement with the menstrual cycle in the women with PCOS $[7,21,32,33]$. Other plausible reason for the disparity include the degree of ultrasound scan resolution used in the study.

This study showed that infertile women with polycystic ovarian syndrome significantly have anovulation with menstrual cycle affectation such as Oligomenorrhoea in few of them and majority having normal duration of menstrual flow. This is similar to reports in some previous studies around the globe $[13,21,23]$. The only difference is that the percentage of infertile women with polycystic ovaries that have oligomenorrhoea in this study was less than the percentage with oligomenorrhoea in these other studies [20,2,31]. Oligomenorrhoea is a feature of annovulatory cycles, even in these women. The presence of hirsutism and acne, as in other studies, were significantly higher among infertile women with PCOS than in those with normal ovaries $(\mathrm{P}<0.001, \mathrm{P}=0.03$ respectively). These are clinical evidence of hyperandrogenaemia. Elevated serum levels of testosterone in the women with PCOS, in this study, reflected closely these clinical features of hyperandrogenism which has also been demonstrate in other studies [20,27-31].

The mid-luteal progesterone level in this study, was significantly lower in infertile women with PCOS when compared to infertile women with normal ovaries. Implying reduced ovulation in women with PCOS. In a similar study it was shown that $90.7 \%$ of the non-PCOS group versus $7.5 \%$ of the PCOS group showed ovulatory cycles and another study also showed a low progesterone level (confirming anovulation) in patients with PCOS [26,27].

The data showed that over $80 \%$ of those with PCOS had elevated testosterone levels and over $90 \%$ had at least one polycystic ovary. Anovulation tend to be frequent with a low mid-luteal phase progesterone despite fairly regular menstrual cycle in the majority of these infertile women with PCOS. The predominant phenotype for this group of infertile women with PCOS appears to be that of hyperandrogenaemia, polycystic ovary morphology.

In this study, both the infertile women with normal ovaries and those with polycystic ovarian syndrome have increased body mass index. Over $90 \%$ of those with PCOS and $72 \%$ of the women with normal ovaries have BMI $>25$. Association of PCOS with obesity had been noted in infertile women in some regions of the world but absent in women in other regions [24,31-36]. It is difficult to associate the obesity in this study with PCOS, however obesity is known to exacerbate symptoms of PCOS and to cause poor response to ovulation induction agents in patients with PCOS [37].

In this study, the mean serum LH and FSH levels in those with PCOS were more than in those with normal ovaries. This is similar to the finding of many authors $[24,31,35]$. However, there are inconsistencies in the levels of LH and FSH in women with PCOS in different reports by different authors reportedly make the levels of these hormones inappropriate for use as diagnostic criteria for PCOS

This study revealed that there was no significant difference in mean prolactin level between infertile women with PCOS and those without PCOS as previously observed [27,36]. Hyperprolactinemia produces similar symptoms to PCOS and need to be excluded in patients suspected to have PCOS [35]. Prolactin levels have however been shown to be unaffected in patients with PCOS [33].

The limitations in this study include control of the blood samples collection considering the specific days in the menstrual cycle the samples were to be collected. Acne could not be graded and so could not signify degree of acne that is consistent with PCOS. Only total testosterone was measured due to lack of facility to measure free testosterone and sex hormone binding globulin and so, the degree of hyperandrogenism a could have been underestimated. 


\section{References}

1. Loot WE, Amballi AA, Banjo TA (2012) A review of female infertility; Important aetiological factors and management. J Microbiol Biotech Res 2(3): 379-385.

2. Idrisa A (2005) Infertility. In: Kwawukume EY, Emuveyan EE (eds), Comprehensive Gynaecology in the Tropics. Graphic packaging Ltd, Ghana, pp. 333-345.

3. Adamson GD, Baker VL (2003) Sub fertility: Causes, Treatment and Outcome. Best Pract Res Clin Obstet Gynaecol 17(2): 169-185.

4. Brassard M, Ainmelk Y, Baillargeon J (2008) Basic Infertility including Polycystic Ovary Syndrome. Medical Clinic of North America 92(5): 1163-1192.

5. Adam HB, Laven JSE, Tan SL, Dewaily D (2003) Ultrasound assessment of the Polycystic Ovary: International consensus definitions. Human Reprod Update 9(6): 505-514.

6. Balen AH, Conway GS, Kaltsas G, Techatrasak K, Manning PJ, et al. (1995) Polycystic ovary syndrome: the spectrum of the disorder in 1741 patients. Hum Reprod 10(8): 2107-2111.

7. Kovacs GT (2004) Polycystic Ovarian Disease: An Overview. Review in Gynaecological Practice 4(2): 97-104.

8. Fraser IS, Kovacs GT (2004) Current recommendation for the diagnostic evaluation and follow-up of patient presenting with symptomatic polycystic ovary syndrome. Best pract Res Clin Obstet Gynaecol 18(5): 813-823.

9. Barday karbanee N, Siebert TI, Botha MH, Kruger TF (2006) Diagnostic Features of Polycystic Ovary Syndrome. South Afr J Obstet Gynaecol 12(1): 30-35.

10. Hart R, Hickey M, Frank S (2004) Definition, Prevalence and symptoms of polycystic ovaries and polycystic ovary syndrome. Best Pract Res Clin obstet Gynaecol 18(5): 671-683.

11. Norman RJ, Wu R, Stankiewics MT (2004) polycystic ovary syndrome. The Medical Journal of Australia (MJA) 180(3): 132-137.

12. Azziz R, Woods KS, Reyna R, Key TJ, Knochenhauer ES, et al. (2004) The prevalence and features of the polycystic ovary syndrome in an unselected population. J Clin Endocrinol Metab 89(6): 2745-2749.

13. Kauffman RP, Baker TE, Baker VM, DiMarino P, Castracane D, et al. (2008) Endocrine and metabolic differences among phenotypic expressions of polycystic ovary syndrome according to the 2003 Rotterdam consensus criteria. Am J Obstet Gynecol 198(6): 670.e1670.e10.

14. Diamanti-Kandarakis E, Kouli CR, Bergiele AT, Filandra FA, Tsianateli TC, et al. (1999) A survey of the polycystic ovary syndrome in the Greek island of Lesbos: hormonal and metabolic profile. J Clin Endocrinol Metab 84(11): 4006-4011.

15. Archer JS, Chang RJ (2004) Hirsutism and Acne in Polycystic Ovary Syndrome. Best Pract Res clin Obstet Gynaecol 18(5): 737-754.

16. Terapon V, Verathep K, Supreya W, Opas S, Rungaroon S, et al. (2007) Clinical, Endocrine and Ultrasonographic features of Polycystic ovary syndrome in Thai Women. J Obstet Gynaecol Res 33(5): 677-680.

17. Setji TK, Brown AJ (2007) PCOS: Diagnosis and treatment. Am J Med 120(2): 128-132.

18. Maharaja S, Amod A (2009) polycystic ovary syndrome. JEMDSA 14(2): 86-95.

19. Yan-Min M, Rong L, Jie Q, Xiao-Wei Z, Shu-Yu W, et al. (2010) Characteristics of abnormal menstrual and polycystic ovary syndrome in community and hospital population. Chinese Med J 123(16): 21852189.
20. Pembe AB, Abeid MS (2009) Polycystic ovaries and associated clinical and biochemical features among women with infertility in a tertiary hospital in Tanzania. Tanzan J Health Res11(4): 175-180.

21. Rotterdam ESHRE/ASRM-Sponsored PCOS Consensus Workshop Group (2004) Revised 2003 consensus on diagnostic criteria and longterm health risks related to polycystic ovary syndrome. Hum Reprod 19(1): 41-47.

22. Palomba S, Santagni S, Falbo A, La Sala GB (2015) Complications and challenges associated with polycystic ovary syndrome: current perspectives. Int J Womens Health 7: 745-763.

23. Van Balen F, Inhorn M (2002) Interpreting Infertility: A review from the social sciences. In: Inhorn M, Van Balen F (Eds), Infertility around the globe: new thinking on childlessness, gender and reproductive technologies, University of California press, London, UK, pp. 3-32.

24. Obuna JA, Ndukwe EO, Ugboma HAA, Ejikeme BN, Ugboma EW, et al. (2012) Clinical presentation of infertility in an outpatient clinic of a resource poor setting, South East Nigeria. Int J Trop Disease and Health 2(2): 123-131.

25. Baqai Z, Khanam M, Parren S (2010) Prevalence of PCOS in infertile patients. Medical Channel 16(3): 437- 440.

26. Oriji VK, Nyengidiki TK (2005) Ovulation induction in women with PCOS. What is the optimal option.

27. Hussein B, Alalaf S (2013) prevalence and characteristics of polycystic ovary syndrome in a sample of infertile Kurdish women attending IVF infertility centre in Mternity Teaching Hospital of Erbil City. Open J Obstet Gynecol 3: 577- 585.

28. Kristensen SL, Ramiau-Hansen CH, Ernst E, Olsen SF, Bonde JP, et al. (2010) A very large population of young Danish women have polycystic ovaries: is a revision of the Rotterdam criteria needed? Hum Reprod 25(12): 3117-3122.

29. Haq F, Aftab O, Rizvi J (2007) Clinical, Biochemical and Ultrasonographic features of infertile women with Polycystic Ovarian Syndrome. J Coll Physicians Surg Pak 17(2): 76-80.

30. Kousta E, White DM, Cela E, McCarthy MI, Frank S, et al. (1999) The prevalence of polycystic ovaries in women with infertility. Human Reprod 14(11): 2720-2723.

31. Srinivasan R, Chaudry S, Wong E (2010) Polycystic ovarian syndrome. J Obstet Gynaecol Can 32(5): 423-428.

32. Korhonen S, Hippelainen M, Vanhala M, Heinonen S, Niskanen L, et al. (2003) The androgenic sex hormone profile is an essential feature of metabolic syndrome in premenopausal women: a controlled community-based study. Fertil Steril 79: 1327-1334.

33. Dahlgren E, Johansson S, Lindstedt G, Knutsson F, Odén A, et al. (1992) Women with polycystic ovary syndrome wedge resected in 1956 to 1965: a long-term follow-up focusing on natural history and circulating hormones. Fertil Steril 57(3): 505-513.

34. Alnakash AH, Al-Taee NK (2007) Polycystic ovarian syndrome: the correlation between LH/FSH ratio and disease manifestation. Middle East Fertility Society Journal 12(1): 35-40.

35. Haoula Z, Salman M, Atiomo W (2012) Evaluating the association between endometrial cancer and polycystic ovary syndrome. Human Reprod 27(5): 1327-1331.

36. Benjamin F, Toles AW, Seltzer VL, Deutsch S (1994) Excessive Ostradiol Secretion in polycystic ovary disease. Am J Obstet Gynecol 171(6): 1673.

37. Villavicencio A, Goyeneche A, Telleria C, Bacallao K, Gabler F, et al. (2009) Involvement of Akt, Ras and cell cycle regulators in the potential development of endometrial hypaplasia in women with polycystic ovary syndrome. Gynecol Oncol 115(1): 102-107. 


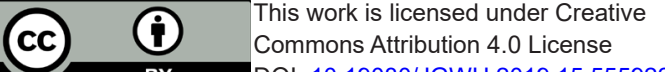

DOI: 10.19080/JGWH.2019.15.555922
Your next submission with Juniper Publishers will reach you the below assets

- Quality Editorial service

- Swift Peer Review

- Reprints availability

- E-prints Service

- Manuscript Podcast for convenient understanding

- Global attainment for your research

- Manuscript accessibility in different formats

( Pdf, E-pub, Full Text, Audio)

- Unceasing customer service

Track the below URL for one-step submission

https://juniperpublishers.com/online-submission.php 